\title{
Virosecurinine induces apoptosis in human leukemia THP-1 cells and other underlying molecular mechanisms
}

\author{
GANG ZHANG ${ }^{1}$, XIAOHUI GAO ${ }^{2}$, HUI ZENG $^{1}$, YUAN LI $^{1}$ and XIAOJUN GUO ${ }^{1}$ \\ Departments of ${ }^{1}$ Hematology and ${ }^{2}$ Pediatrics, First Affiliated Hospital of Jiaxing University, \\ Jiaxing, Zhejiang 314000, P.R. China
}

Received April 8, 2016; Accepted October 13, 2017

DOI: $10.3892 / \mathrm{ol} .2017 .7437$

\begin{abstract}
Virosecurinine, a primary alkaloid from Securinega suffruticosa plant is known as a potent differentiation-inducing agent in acute leukemia cells. The present study aimed to investigate the effects and underlying mechanisms of virosecurinine on human leukemia THP-1 cells in vitro. The effects of virosecurinine on cell proliferation were assessed by CCK-8. The effects on apoptosis and cell cycle were assessed by staining with annexin $\mathrm{V}$-fluorescein isothiocyanate and propidium iodide, respectively followed by flow cytometric analysis. The apoptotic cell bodies were observed using a transmission electron microscope, while the mRNA expression of phosphoinositide 3-kinase (PI3K), protein kinase B (AKT), mechanistic target of rapamycin (mTOR) and phosphatase and tensin homolog (PTEN) in THP-1 was evaluated by reverse transcription-quantitative polymerase chain reaction (RT-qPCR). Treatment with virosecurinine was able to decrease the viability of THP-1 cells in a dose- and time-dependent manner. The $\mathrm{IC}_{50}$ values of virosecurinine at 24,48 , and $72 \mathrm{~h}$ post-treatment were $68.128,23.615$, and $13.423 \mu \mathrm{mol} / \mathrm{l}$, respectively. Cell cycle was arrested at the G1/S phase in virosecurinine-treated cells; however, not in untreated control cells. Numerous apoptotic bodies were observed in the THP-1 cells, which were treated with $12.5 \mu \mathrm{mol} / \mathrm{l}$ virosecurinine for $48 \mathrm{~h}$. RT-qPCR indicated that treatment with virosecurinine resulted in upregulated PTEN expression and downregulated expression of PI3K, AKT and mTOR in THP-1 cells. The present study demonstrated that treatment with virosecurinine was able to inhibit proliferation and induce apoptosis in THP-1cells by exerting an inhibitory effect on the activation of PI3K/AKT/mTOR signaling pathways. Therefore, our data suggested that virosecurinine is a promising anti-tumor agent for the treatment of acute monocytic leukemia.
\end{abstract}

Correspondence to: Professor Xiaojun Guo, Department of Hematology, First Affiliated Hospital of Jiaxing University, 1882 South Zhonghuan Road, Jiaxing, Zhejiang 314000, P.R. China E-mail: 13967379309@139.com

Key words: virosecurinine, apoptosis, acute monocytic leukemia, THP-1 cells, signaling pathways

\section{Introduction}

Acute leukemia is characterized as a heterogeneous clonal disease with undifferentiated malignant growth. In total, $\sim 140,000$ people are diagnosed with acute leukemia worldwide annually (1). Acute myeloid leukemia (AML) is the most common type of acute leukemia in aging adults and is considered responsible for the highest annual mortality rate by leukemia globally (2). However, AML remains one of the most difficult malignant hematological diseases to treat, and has the lowest survival rate among all types of leukemia (3). Therefore, a deeper insight into the molecular etiology of AML will allow the development of an effective natural anti-tumor drug.

Several recent developments have been instigated for high efficacy and low toxicity antitumor drugs. Securinega alkaloids have been isolated from the Euphorbiaceae family of plants. Typically, securinine, an alkaloid from the leaves of Securinega suffruticosa, was initially isolated by a Russian scientist, Ia A, in 1956. Securinine has been structurally characterized into two optical isomers: L-securinine and virosecurinine, by Chinese scientists in 1963 (4). As a natural product, securinine was observed to exert several important roles in biological systems (5). Securinine is able to act as a $\gamma$-aminobutyric acid receptor antagonist (6) and exhibit antimalarial (7) and antibacterial activities (8). Li et al (9) have demonstrated that virosecurinine is able to exhibit apoptotic activity in human breast cancer MCF-7 cells, whereas Zhang et al (10) have demonstrated its apoptotic activity in human chronic myeloid leukemia K562 cells. Therefore, virosecurinine may be potentially used for cancer treatment.

Apoptosis is a physiological cell removal mechanism that is critical in the cancer cell cycle (11). Cancer cells have evolved multiple molecular mechanisms against the onset of apoptosis, and therefore the signaling pathways induced by natural products, including L-securinine, betulinic acid and resveratrol, may serve as key factors for antitumor activities (12). One such example is the phosphatidylinositol 3-kinase/protein kinase $\mathrm{B} / \mathrm{mammalian}$ target of rapamycin (PI3K/AKT/mTOR) signaling pathway, which is crucial for proliferation, development and cell death (13). Constitutive activation of the $\mathrm{PI} 3 \mathrm{~K} / \mathrm{AKT} / \mathrm{mTOR}$ signaling pathway is associated with the progression and pathogenesis of a broad spectrum of various types of human cancer, including acute leukemia (14-16). Therefore, investigating novel approaches for inhibiting this 
signaling pathway in order to develop targeted therapeutics while limiting the side effects is vital for increasing treatment efficacy and improving prognosis in patients (17).

The present study investigated the effects and underlying mechanisms of virosecurinine on apoptosis in human AML THP-1 cells. Furthermore, the present study also searched for natural anti-tumor drugs that exhibit a high efficacy and low toxicity.

\section{Materials and methods}

Chemicals. Virosecurinine (Fig. 1) was provided by the Institute of Traditional Chinese Medicine and Natural Products, Jinan University (Guangzhou, China). Cell Counting Kit-8 (CCK-8) was purchased from Nanjing KeyGen Biotech Co., Ltd., (catalog no. KGA317; Nanjing, China). The cell culture media (RPMI-1640) and solutions were bought from Gibco (Thermo Fisher Scientific, Inc., Waltham, MA, USA).

Cell line and culture. Human AML THP-1 cell lines were obtained from the Key Gen Serving Science Company and were grown in RPMI-1640 (Gibco; Thermo Fisher Scientific, Inc.) with $10 \%$ fetal bovine serum (FBS; Hangzhou Sijiqing Biological Engineering Materials Co., Ltd., Hangzhou, China), $100 \mathrm{IU} / \mathrm{ml}$ penicillin, and $100 \mu \mathrm{g} / \mathrm{ml}$ streptomycin. The cells were grown and maintained at $37^{\circ} \mathrm{C}$ in a humidified incubator with $5 \% \mathrm{CO}_{2}$.

Cell viability analysis. Cell Counting Kit-8 assay (CCK-8; catalog no. KGA317; Nanjing KeyGen Biotech Co., Ltd.) was used to measure cell viability. THP-1 cells in the exponential phase were plated in $100 \mu 1$ into 96-well plates (Corning Incorporated, Corning, NY, USA) at a density of $5 \times 10^{3}$ cells/well. After $24 \mathrm{~h}$ at $37^{\circ} \mathrm{C}$, THP-1 cells were replenished with RPMI-1640 medium containing 10\% FBS and treated with virosecurinine $(200 \mu \mathrm{l} /$ well $)$ at concentrations ranging from 0 to $200 \mu \mathrm{mol} / 1$. Then, the plates were incubated in a humidified incubator for 24,48 , and $72 \mathrm{~h}$ at $37^{\circ} \mathrm{C}$. A total of $10 \mu \mathrm{l}$ CCK-8 solution was added to each well three hours prior to measurement of absorbance. The optical density was measured at $450 \mathrm{~nm}$ with a microplate reader (EL-x 800; BioTek Instruments, Inc., Winooski, VT, USA). Relative cell proliferation inhibition rate (IR) was calculated using the following formula: $\mathrm{IR}=$ (absorbance of the control group-absorbance of the experimental group)/(absorbance of the control group-absorbance of the blank control group)x $100 \%$. All experiments were performed four times.

Transmission electron microscopy. THP-1 cells were seeded at a density of $5 \times 10^{5}$ cells/well in 6 -well plates (Corning Incorporated) with or without $12.5 \mu \mathrm{mol} / 1$ virosecurinine for $48 \mathrm{~h}$ at $37^{\circ} \mathrm{C}$. Subsequently, the cells were harvested and fixed for $2 \mathrm{~h}$ at $4^{\circ} \mathrm{C}$ in $2.5 \%$ chilled glutaraldehyde followed by three washes in $0.1 \mathrm{~mol} / 1$ PBS (Nanjing KeyGen Biotech Co., Ltd.). The cells were then post-fixed at $4^{\circ} \mathrm{C}$ in $1 \%$ osmium tetroxide for $2 \mathrm{~h}$, dehydrated sequentially in 50,70,90 and $100 \%$ ethanol for 15 min each (three times in $100 \%$ ethanol), and embedded in epoxy resin. Consequently, the embedded cells were sliced into 50-60 nm sections and stained with uranyl acetate for $30 \mathrm{~min}$ at room temperature and lead citrate for $30 \mathrm{~min}$ at room temperature, and subsequently observed under a transmission electron microscope (TEM-1011; JEOL, Ltd., Tokyo, Japan).

Apoptosis analysis. For apoptosis analysis, THP-1 cells were cultured in 6-well plates at a density of $3.0 \times 10^{5}$ cells/well for $24 \mathrm{~h}$, and then treated with various concentrations of virosecurinine, $6.25,12.5$ and $25 \mu \mathrm{mol} / \mathrm{l}$, respectively, for $48 \mathrm{~h}$. The cells were washed twice with cold PBS and gently resuspended in $500 \mu \mathrm{l}$ binding buffer. Thereafter, $5 \mu \mathrm{l}$ annexin $\mathrm{V}$-fluorescein isothiocyanate (FITC) (KGA105; Nanjing KeyGen Biotech Co., Ltd.) and propidium iodide (KGA511; Nanjing KeyGen Biotech Co., Ltd.) were added. After 15 min incubation at room temperature in the dark, the cells were subjected to flow cytometric analysis. The fluorescence was measured using a flow cytometer (FACSCalibur; BD Biosciences, Franklin Lakes, NJ, USA) equipped with an argon laser (488 $\mathrm{nm}$ ). The percentage of apoptotic cells was calculated using the FACScan software (version 6.0; BD Biosciences).

Cell cycle analysis. For cell cycle analysis, THP-1 cells were cultured in 6-well plates and treated with virosecurinine as described above. The cells were then washed, harvested and fixed with $70 \%$ ethanol at $4^{\circ} \mathrm{C}$ overnight. Subsequently, the cells were treated with Tris- $\mathrm{HCl}$ buffer ( $\mathrm{pH}$ 7.4) containing $1 \%$ RNase A (KGA511; Nanjing KeyGen Biotech Co., Ltd.) and stained with propidium iodide (PI, 5 mg/ml; Nanjing KeyGen Biotech Co., Ltd.). The distribution of cells with different DNA contents was determined by flow cytometry.

Reverse transcription-quantitative polymerase chain reaction $(R T-q P C R)$. RT-qPCR assays were performed on THP-1 cells treated with or without virosecurinine in order to evaluate the expression of PI3K, AKT, mTOR and phosphatase and tensin homolog (PTEN). Total RNA was isolated from THP-1 cells with TRIzol reagent (Invitrogen; Thermo Fisher Scientific, Inc.) according to the manufacturer's protocol. A two-step reverse transcription PCR was performed. First-strand cDNA synthesis was performed using the ProSTARt First Strand RT-PCR kit (catalog no. PC0002; Fermentas; Thermo Fisher Scientific, Inc.) according to the manufacturer's instructions. The efficiency of cDNA synthesis from each sample was estimated by PCR with GAPDH-specific primers. CK8 and GAPDH genes were quantified by RT-PCR for mRNA level and as an endogenous control, respectively. Subsequently, $20 \mu 1$ reaction mixture was used for qPCR, using a qPCR kit (catalog no. DA7600; OriGene Technologies, Inc., Rockville, MD, USA), which consisted of 40 cycles: Denaturation (15 sec at $\left.94^{\circ} \mathrm{C}\right)$, annealing $\left(20 \mathrm{sec}\right.$ at $\left.60^{\circ} \mathrm{C}\right)$ and extension $(40 \mathrm{sec}$ at $72^{\circ} \mathrm{C}$ ). The reaction mixture (catalog no. EP0702; Fermentas; Thermo Fisher Scientific, Inc.) contained $10 \mu \mathrm{M}$ of each primer, $2 \mu \mathrm{l}$ of 2x QuantiTect SYBR Green RT-PCR Master Mix, $10 \mu \mathrm{l}$ QuantiTect reverse transcriptase mix, and $8 \mu \mathrm{l}$ nuclease-free water. The relative quantification was analyzed by the $2^{-\Delta \Delta \mathrm{Cq}}$ method (18) with GAPDH as the housekeeping gene and the control cells as the baseline. The results were expressed as fold changes. Each experiment was repeated three times. The sequences of the primers used are as follows: PI3K forward, 5'-GGGGATGATTTACGGCAAGATA-3' and reverse, 5'-CACCACCTCAATAAGTCCCACA-3'; AKT forward, 5'-GCAGCACGTGTACGAGAAGA-3' and reverse, 


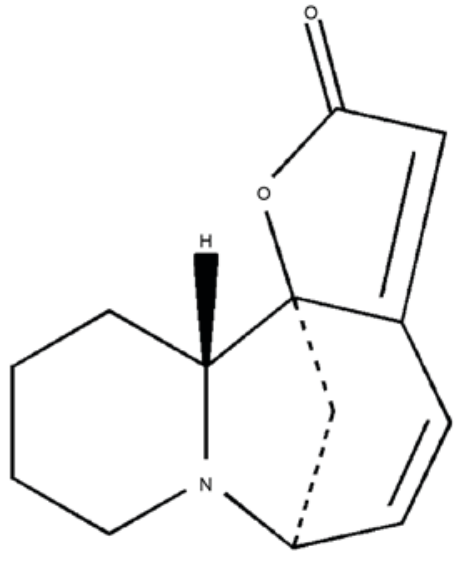

Figure 1. Structure of virosecurinine.

5'-GGTGTCAGTCTCCGACGTG-3'; mTOR forward, 5'-ATT TGATCAGGTGTGCCAGT-3', and reverse, 5'-GCTTAGGAC ATGGTTCATGG-3'; PTEN forward, 5'-CAAGATGATGTT TGAAACTATTCCAATG-3', and reverse, 5'-CCTTTAGCT GGCAGACCACAA-3'; GAPDH forward, 5'-TGTTGCCAT CAATGACCCCTT-3', and reverse, 5'-CTCCACGACGTA CTCAGCG-3'.

Statistical analysis. All data are represented as the mean \pm standard deviation. SPSS (version 18.0; SPSS Inc., Chicago, IL, USA) was used for statistical analyses. Statistically significant differences between the groups were analyzed by Student's t-test, and multiple comparisons were performed using one-way analysis of variance followed by Tukey's test. $\mathrm{P}<0.05$ was considered to indicate a statistically significant difference.

\section{Results}

Virosecurinine treatment inhibits growth THP-1 cells in vitro. In order to determine the mechanistic effects of virosecurinine-induced apoptosis, CCK-8 assay was employed to investigate the proliferation of THP-1 cells. The inhibitory effect on proliferation was determined by treating cells with a range of virosecurinine concentrations ranging from 0 to $200 \mu \mathrm{mol} / \mathrm{l}$ for 24,48 and $72 \mathrm{~h}$, respectively. The assay revealed that treatment with virosecurinine was able to significantly inhibit the proliferation of THP-1 cells in a dose- and time- dependent manner (Fig. 2). The $\mathrm{IC}_{50}$ values at 24,48 and $72 \mathrm{~h}$ following treatment were $68.128,23.615$ and $13.423 \mu \mathrm{mol} / 1$, respectively.

Ultrastructure of THP-1 cells. The ultra-structural analysis of virosecurinine-induced apoptosis in THP-1 cells was carried out by electron microscopy (Fig. 3). The appearance of apoptotic bodies in THP-1 cells that were treated with $12.5 \mu \mathrm{mol} / 1$ virosecurinine for $48 \mathrm{~h}$ (Fig. 3B) confirmed that apoptosis was taken place in these treated cells. Similar results were not observed in untreated cells (Fig. 3A).

Virosecurinine treatment inhibits cell cycle progression in THP-1 cells. To understand the mechanisms of virosecurinine-induced THP-1 cell apoptosis, flow cytometric cell cycle analysis of THP-1 cells following treatment with

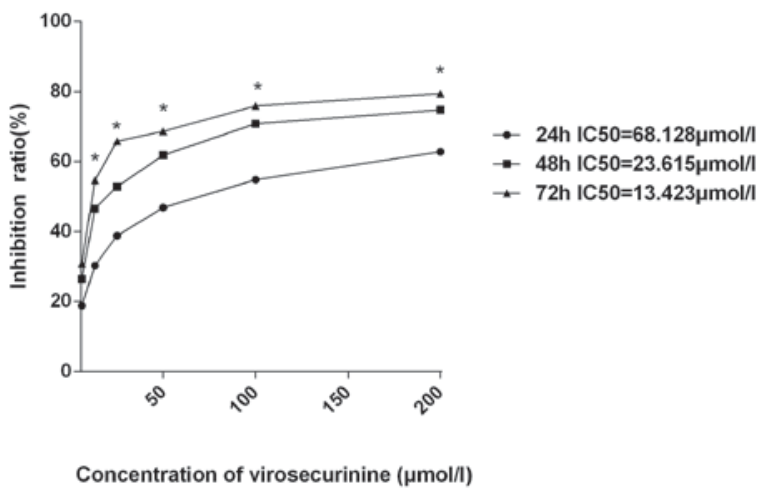

Figure 2. Dosage and time dependent inhibition of THP-1 cells by virosecurinine. ${ }^{*} \mathrm{P}<0.05$ vs. untreated control.

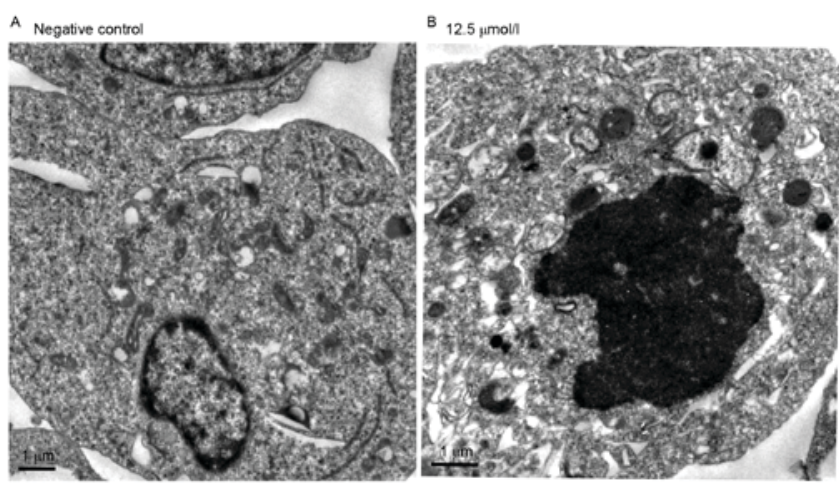

Figure 3. Electron micrographs demonstrating the ultrastructure of THP-1 cells, which were treated with $12.5 \mu \mathrm{mol} / 1$ virosecurinine for $48 \mathrm{~h}$. (A) A small number of apoptotic bodies were observed in THP-1 cells that were treated without virosecurinine for $48 \mathrm{~h}$ (control). (B) Numerous apoptotic bodies were observed in virosecurinine treated-THP-1 cells.

$0,6.25,12.5$ and $25 \mu \mathrm{mol} / 1$ virosecurinine, respectively, for $48 \mathrm{~h}$ was performed. The results demonstrated that treatment with virosecurinine resulted in cell-cycle arrest in the G1 phase. (Fig. 4). Notably, a sub-G1 peak was observed, which represented an apoptotic population as a response to virosecurinine treatment.

Virosecurinine treatment induces apoptosis in THP-1 cells in vitro. Apoptotic rate in THP-1 cells treated with virosecurinine was determined by FITC-annexin V and PI double staining followed by flow cytometric analysis. The quantification of cells in each quadrant in Fig. 5 are representative of necrosis (C1), late apoptosis (C2), live cells (C3) and early apoptosis (C4). This indicated that virosecurinine concentration was directly proportional to the rate of apoptosis in THP-1 cells. The proportion of apoptotic cells treated with $6.25,12.5$ and $25 \mu \mathrm{mol} / \mathrm{l}$ of virosecurinine for $48 \mathrm{~h}$ was $25.47,38.29$ and $64.31 \%$, respectively (Fig. 5).

Virosecurinine treatment affects the expression of genes in the PI3K/AKT/mTOR signaling pathway in THP-1 cells. To further elucidate the mechanism underlying virosecurinine-induced apoptosis in THP-1 cells, the expression of PI3K, AKT, mTOR and PTEN in treated and control THP-1 cells was evaluated. 

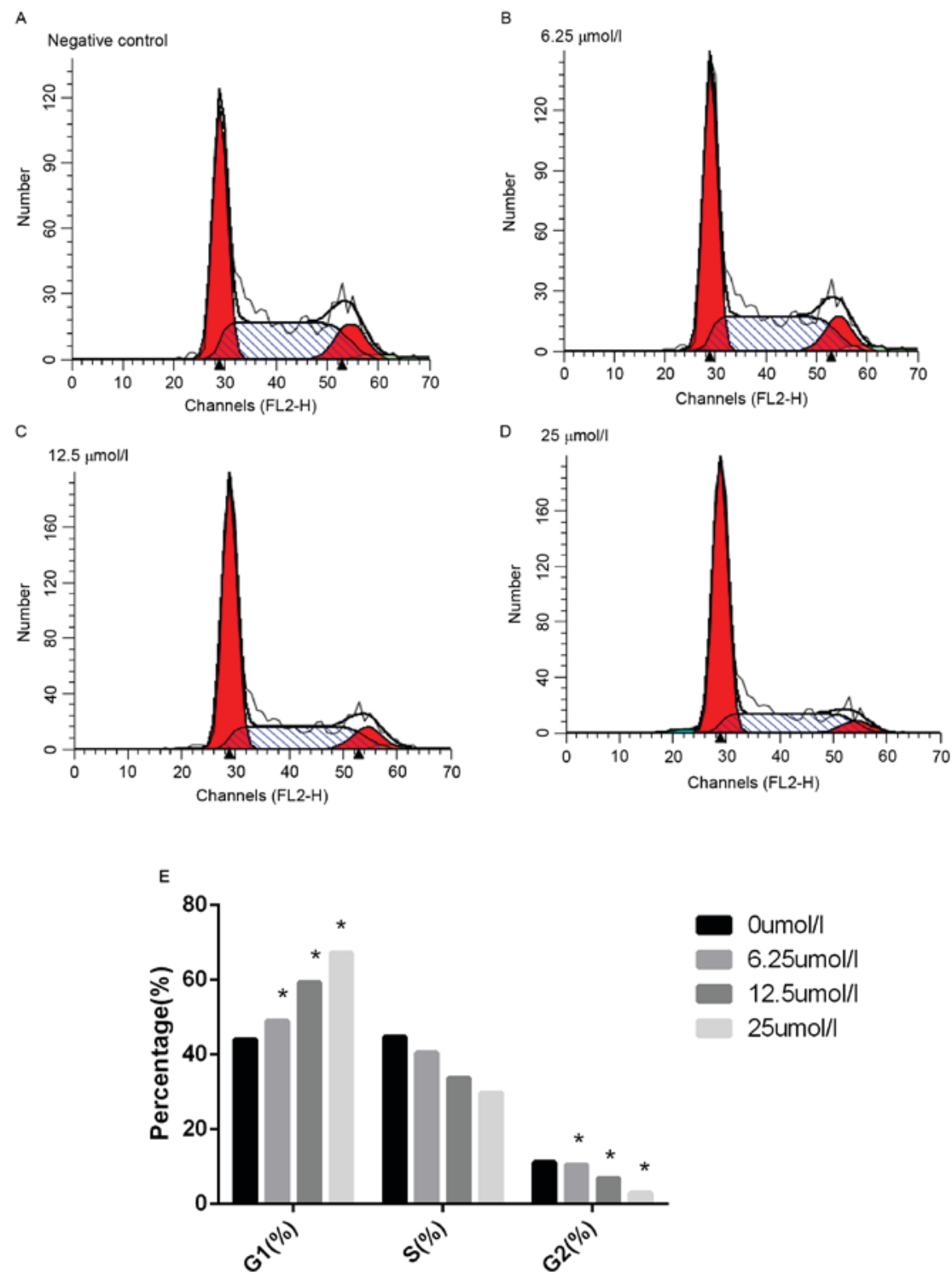

Figure 4. Flow cytometric analysis of cell cycle of cells treated with virosecurinine. (A) Flow cytometric analysis of normal THP-1 cells and cells treated with (B) 6.25 , (C) 12.5 and (D) $25 \mu \mathrm{mol} / 1$ virosecurinine for $48 \mathrm{~h}$. (E) Cell cycle of THP-1 cells treated with virosecurinine at different concentrations for $48 \mathrm{~h}$ and detected using flow cytometry. The results demonstrated that the cell cycle was arrested at the G0/G1 phase when treated with virosecurinine. "P $<0.05$ vs. control.

RT-qPCR analysis revealed that treatment with virosecurinine was able to downregulate the level of PI3K, AKT and mTOR expression and upregulate the expression of PTEN $(\mathrm{P}<0.05$; Fig. 6). These results suggested that virosecurinine-induced apoptotic cell death was associated with the activation of PI3K, AKT, mTOR and PTEN.

\section{Discussion}

AML treatment remains a major challenge due to poor efficacy of the current chemotherapeutics. Therefore, investigating natural plants as resources for antitumor agents is an increasingly important topic in cancer research. Herein, the effect of virosecurinine on the proliferation of human AML THP-1 cells was investigated. In the present study, it was demonstrated that virosecurinine was able to inhibit proliferation of THP-1 cells at low concentrations. The $\mathrm{IC}_{50}$ values were determined to be $68.128,23.615$, and
$13.423 \mu \mathrm{mol} / 1$, respectively at 24,48 and $72 \mathrm{~h}$ post-treatment. The US National Cancer Institute Plant Screening Program demonstrated in vitro cytotoxicity of a crude extract, with a $\mathrm{IC}_{50}$ value of $<20 \mu \mathrm{g} / \mathrm{ml}(919 \mu \mathrm{mol} / \mathrm{l})$ following incubation between 48 and $72 \mathrm{~h}$ (19). Therefore, the present study exhibited the in vitro cytotoxic activity of virosecurinine in THP-1 cells. This result also illustrated that the proliferation of THP-1 cells was markedly inhibited by virosecurinine in a dose- and time-dependent manner. Moreover, apoptosis was also confirmed by the appearance of apoptotic bodies, and a sub-G1 peak was observed in THP-1 cells that were treated with $25 \mu \mathrm{mol} / 1$ virosecurinine for $48 \mathrm{~h}$.

Several studies demonstrated that apoptosis and autophagy are two predominant cell death routes in various types of cancer $(20,21)$. Apoptosis or programmed cell death can be activated by anti-neoplastic drugs, which interfere with cell proliferation mediated by (22). In agreement with previous studies, the present study also demonstrated that treatment 
A Negative control

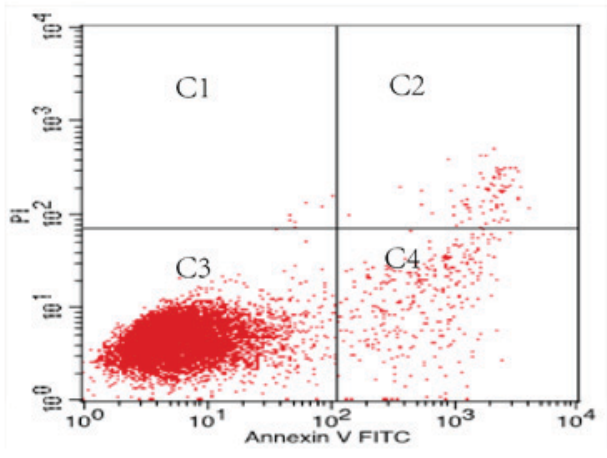

C $12.5 \mathrm{umol} / \mathrm{l}$

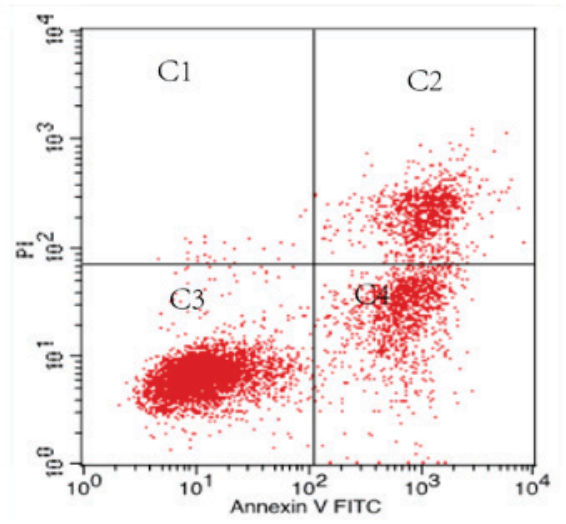

B $6.25 \mathrm{umol} / \mathrm{l}$

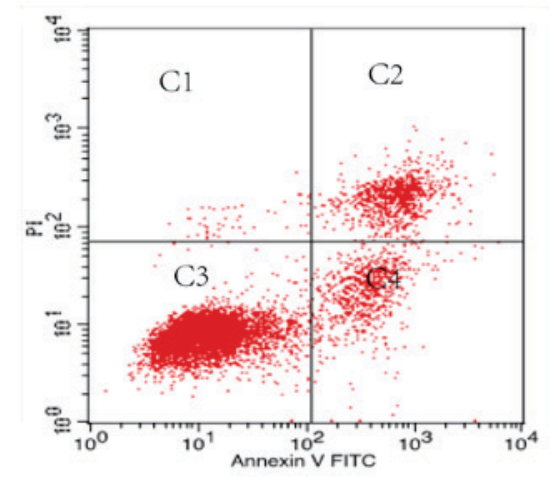

D 25umol/1

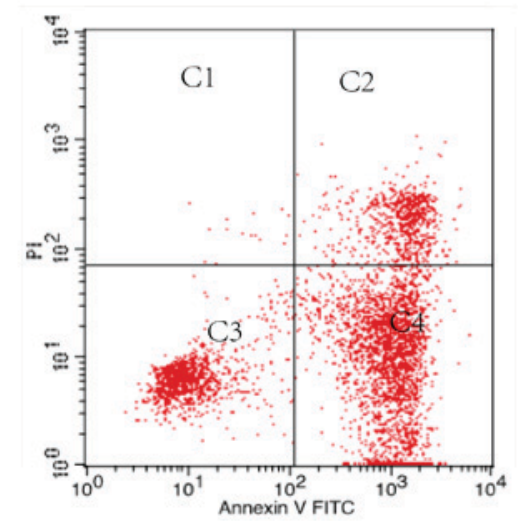

concentration of virosecurinine (umol/l)

Figure 5. Flow cytometric analysis of apoptotic cells treated with virosecurinine. Apoptotic rates analyzed by fluorescence-activated cell sorting following treatment with virosecurinine. THP-1 cell. A, normal THP-1 cells; B, C and D demonstrate THP-1 cells treated with $6.25,12.5$ and $25 \mu$ mol/1 of virosecurinine for $48 \mathrm{~h}$ respectively.

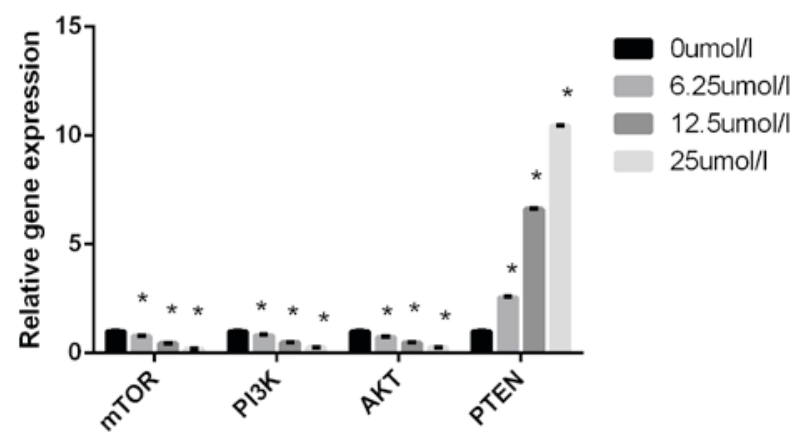

Figure 6. Reverse transcription-quantitative polymerase chain reaction analysis of gene expression of mTOR, PI3K, AKT and PTEN in THP-1 cells treated with $6.25,12.5$ and $25 \mu \mathrm{mol} / 1$ virosecurinine for $48 \mathrm{~h}$. mTOR, mechanistic target of rapamycin; PI3K, phosphoinositide 3-kinase; PTEN, phosphatase and tensin homolog. ${ }^{*} \mathrm{P}<0.05$ vs. the control.

with virosecurinine was able to induce apoptosis in AML cell line THP-1 via an inhibitory effect on the cell apoptosis. The PI3K/AKT/mTOR signaling pathway is one of the major intracellular pathways, which are tightly regulated under normal physiological conditions. However, the PI3K/AKT/mTOR signaling pathway is frequently activated in human cancer types $(23,24)$. Upon stimulation by receptor tyrosine kinases or G-protein coupled receptors, PI3K is translocated to the plasma membrane, resulting in the phosphorylation of phosphatidylinositol 4,5-bisphosphate to phosphatidylinositol 3,4,5-triphosphate. In previous studies, dysregulation of PI3K/AKT/mTOR signaling has been observed to exhibit a vital role in the onset of various types of human cancer $(25,26)$. This may be an innate characteristic of the signaling pathway or the consequence of mutations that are able to activate or regulate the PI3K/AKT/mTOR signaling pathway. Some of these mutations include activating mutations in Fms-like tyrosine kinase, $\mathrm{N}$ - or KRAS, and c-kit tyrosine kinase receptor (27-29). The phosphatase, PTEN, functions as a tumor suppressor through negative regulation of the PI3K/AKT/mTOR signaling pathway (30). Inactivation of PTEN leads to increased ATP-binding cassette transporter G2 expression, which inhibits the PI3K/AKT/mTOR signaling pathway, thereby designating it as a potential therapeutic target in the treatment of AML (31). The factors modulating PI3K and mTOR have been accentuated to function in a synergistic association with the current chemotherapeutic drugs in the treatment of AML $(32,33)$.

To further investigate the molecular etiology, analysis of the four apoptosis-linked genes demonstrated that treatment with virosecurinine was able to downregulate PI3K, AKT and mTOR gene expression and upregulate the PTEN expression in THP-1 cells. Herein, to the best of our knowledge, it was demonstrated for the first time that virosecurinine is able to 
induce apoptosis in THP-1 cells, which is regulated by altered expression of PI3K, AKT, mTOR and PTEN. These results suggest that virosecurinine is an effective agent for suppressing the proliferation of AML THP-1 cells and that this may be partially mediated by the downregulation of PI3K, AKT and mTOR and upregulation of PTEN.

In the present study, it was indicated that virosecurinine may be a potential therapeutic for the prevention and treatment of AML.

\section{Acknowledgements}

The present study was supported by the Jiaxing Haematology Key Discipline Fund (grant no. 04-Z-13). The authors would like to thank the Institute of Traditional Chinese Medicine \& Natural Products, Jinan University (Guangdong, China) for providing a pure sample of virosecurinine.

\section{References}

1. Elert E: Living with leukaemia. Nature 498: S2-S3, 2013.

2. O'Donnell MR, Tallman MS, Abboud CN, Altman JK, Appelbaum FR, Arber DA, Attar E, Borate U, Coutre SE, Damon LE, et al: Acute myeloid leukemia, version 2.2013. J Natl Compr Canc Netw 11: 1047-1055, 2013.

3. Deschler B and Lübbert M: Acute myeloid leukemia: Epidemiology and etiology. Cancer 107: 2099-2107, 2006.

4. Saito S, Kotera K, Shigematsu N, Ide A, Sugimoto N, Horii Z, Hanaoka M, Yamawaki Y and Tamura Y: Structure of securinine. Tetrahedron 19: 2085-2099, 1963

5. Chen CR, Xia YH, Yao SY, Zhang Q, Wang Y and Ji ZN: Virosecurinine induces apoptosis by affecting Bcl-2 and Bax expression in human colon cancer SW480 cells. Pharmazie 67: 351-354, 2012

6. Beutler JA, Karbon EW, Brubaker AN, Malik R, Curtis DR and Enna SJ: Securinine alkaloids: A new class of GABA receptor antagonist. Brain Res 330: 135-140, 1985.

7. Weenen H, Nkunya MH, Bray DH, Mwasumbi LB, Kinabo LS, Kilimali VA and Wijnberg JB: Antimalarial compounds containing an alpha,beta-unsaturated carbonyl moiety from Tanzanian medicinal plants. Planta Med 56: 371-373, 1990.

8. Mensah JL, Lagarde I, Ceschin C, Michel G, Gleye J and Fouraste I: Antibacterial activity of the leaves of Phyllanthus discoideus. J Ethnopharmacol 28: 129-133, 1990.

9. Li M, Han S, Zhang G, Wang Y and Ji Z: Antiproferative activity and apoptosis-inducing mechanism of L-securinine on human breast cancer MCF-7 cells. Pharmazie 69: 217-223, 2014.

10. Zhang G, Li M, Han S, Chen D, Wang Y, Ye W3 and Ji Z: Induction of human chronic myeloid leukemia K562 cell apoptosis by virosecurinine and its molecular mechanism. Mol Med Rep 10: 2365-2371, 2014.

11. Lima RT, Busacca S, Almeida GM, Gaudino G, Fennell DA and Vasconcelos MH: MicroRNA regulation of core apoptosis pathways in cancer. Eur J Cancer 47: 163-174, 2011.

12. Fulda S: Modulation of apoptosis by natural products for cancer therapy. Planta Med 76: 1075-1079, 2010.

13. Carnero A, Blanco-Aparicio C, Renner O, Link W and Leal JF: The PTEN/PI3K/AKT signalling pathway in cancer, therapeutic implications. Curr Cancer Drug Targets 8: 187-198, 2008.

14. Schmidt-Kittler O, Zhu J, Yang J, Liu G, Hendricks W, Lengauer C, Gabelli SB, Kinzler KW, Vogelstein B, Huso DL and Zhou S: PI3K $\alpha$ inhibitors that inhibit metastasis. Oncotarget 1: 339-348, 2010

15. Peng C, Chen Y, Li D and Li S: Role of PTEN in leukemia stem cells. Oncotarget 1: 156-160, 2010.
16. Kharas MG, Okabe R, Ganis JJ, Gozo M, Khandan T, Paktinat M, Gilliland DG and Gritsman K: Constitutively active Akt depletes hematopoietic stem cells and induces leukemia in mice. Blood 115: 1406-1415, 2010

17. Dancey JE, Bedard PL, Onetto N and Hudson TJ: The genetic basis for cancer treatment decisions. Cell 148: 409-420, 2012

18. Livak KJ and Schmittgen TD: Analysis of relative gene expression data using real-time quantitative PCR and the 2(-Delta Delta C(T)) method. Methods 25: 402-408, 2001

19. Castello-Branco MVS, Tavares JF, Silva MS, Barbosa Filho JM, Anazetti MC, Frungillo L, Haun M, Melo Diniz MF and Melo PS: Xylodiol from Xylopia langsdorfiana induces apoptosis in HL60 cells. Rev Bras Farmacogn 21: 1035-1042, 2011.

20. Subramaniya BR, Srinivasan G, Sadullah SS, Davis N, Subhadara LB, Halagowder D and Sivasitambaram ND: Apoptosis inducing effect of plumbagin on colonic cancer cells depends on expression of COX-2. PLoS One 6: e18695, 2011.

21. Li YC, He SM, He ZX, Li M, Yang Y, Pang JX, Zhang X, Chow K, Zhou Q, Duan W, et al: Plumbagin induces apoptotic and autophagic cell death through inhibition of the PI3K/Akt/mTOR pathway in human non-small cell lung cancer cells. Cancer Lett 344: 239-259, 2014.

22. Nahata A, Saxena A, Suri N, Saxena AK and Dixit VK: Sphaeranthus indicus induces apoptosis through mitochondrial-dependent pathway in HL-60 cells and exerts cytotoxic potential on several human cancer cell lines. Integr Cancer Ther 12: 236-247, 2013.

23. Zhao L and Vogt PK: Class I PI3K in oncogenic cellular transformation. Oncogene 27: 5486-5496, 2008.

24. Polivka J Jr and Janku F: Molecular targets for cancer therapy in the PI3K/AKT/mTOR pathway. Pharmacol Ther 142: 164-175, 2014.

25. Sokolosky ML, Stadelman KM, Chappell WH, Abrams SL, Martelli AM, Stivala F, Libra M, Nicoletti F, Drobot LB, Franklin RA, et al: Involvement of Akt-1 and mTOR in sensitivity of breast cancer to targeted therapy. Oncotarget 2: 538-550, 2011.

26. Altman JK, Sassano A and Platanias LC: Targeting mTOR for the treatment of AML. New agents and new directions. Oncotarget 2: 510-517, 2011

27. Muranyi AL, Dedhar S and Hogge DE: Combined inhibition of integrin linked kinase and FMS-like tyrosine kinase 3 is cytotoxic to acute myeloid leukemia progenitor cells. Exp Hematol 37: 450-460, 2009

28. Faderl S, Pal A, Bornmann W, Albitar M, Maxwell D, Van Q, Peng Z, Harris D, Liu Z, Hazan-Halevy I, et al: Kit inhibitor APcK110 induces apoptosis and inhibits proliferation of acute myeloid leukemia cells. Cancer Res 69: 3910-3917, 2009.

29. Birkenkamp KU, Geugien M, Schepers H, Westra J,Lemmink HH and Vellenga E: Constitutive NF-kappaB DNA-binding activity in AML is frequently mediated by a Ras/PI3-K/PKB-dependent pathway. Leukemia 18: 103-12, 2004.

30. Maiuri MC, Tasdemir E, Criollo A, Morselli E, Vicencio JM, Carnuccio R and Kroemer G: Control of autophagy by oncogenes and tumor suppressor genes. Cell Death Differ 16: 87-93, 2009.

31. Huang FF, Wu DS, Zhang L, Yu YH, Yuan XY, Li WJ, Chen XP, Zhao XL, Chen FP and Zeng H: Inactivation of PTEN increases ABCG2 expression and the side population through the PI3K/Akt pathway in adult acute leukemia. Cancer Lett 336: 96-105, 2013.

32. Xu Q, Thompson JE and Carroll M: mTOR regulates cell survival after etoposide treatment in primary AML cells. Blood 106: 4261-4268, 2005

33. Batista A, Barata JT, Raderschall E, Sallan SE, Carlesso N, Nadler LM and Cardoso AA: Targeting of active mTOR inhibits primary leukemia $\mathrm{T}$ cells and synergizes with cytotoxic drugs and signaling inhibitors. Exp Hematol 39: 457-472.e3, 2011.

his work is licensed under a Creative Commons

Attribution-NonCommercial-NoDerivatives 4.0 International (CC BY-NC-ND 4.0) License. 